\title{
毫展 望言
}

\section{'88 年秋季大会を迎えるにあたって}

\author{
守 永 健 一 \\ Kenichi MOIRINAGA
}

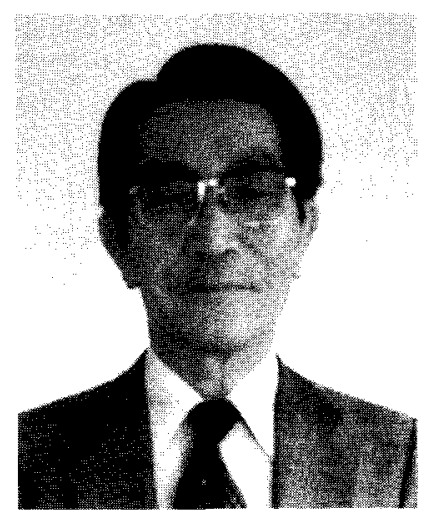

'8 年電気化学秋季大会は9月 25 日, 26 日の 2 日間埼玉大学工 学部で開かれることになりました，最初の話があって学内関係者が 集まったのが昨年 9 月，学外からの応援在願いして正式に実行委 員会が 4 月に発足し，プログラム編成も予定どおり終わり，大会を 目指して準備を進めているところです。

埼玉大学が秋季大会をお引き受けするのは'81 年度に続いて今回 が 2 度目になります。前回の発表件数がおよそ 150 件であったのに 比べ，本年はその倍近くの講演発表が予定されています。，発表件数 だけで学会の活動状況を云々することは勿論できないでしょうが, 世話人側としてはたいんん張り合いがあります。このように，電気 化学が活気を取り㞍したのは，電気化学の取り扱う対象がこの 10 数年間に急激に拡がってきたことと関連するように思われます，新 しい分野が拓かれると，これまでにない新しい考え方の芽生えが期 待されるという意味で，これはよろこばしいことです。しかし，目 覚ましい成果上進展が办られる…万で，研究の実用性上効率性が強 調されるあまり，一見無䭾と思われるような仕事や落ち着いた研究 がやり難くなったというようなことはないでしょうか, 一寸ばかり 気懸りです.

学部や大学院在学時に電気化学の講義を受けたことのない私が大 会の実行委員長をお引き受けすることは，いささか場違いな気持が ないでむありません，しかし，「好きなこよをやった方がいです よ」という恩師の言葉に励まされ，錯塩のポーラログラフィーをて がけることになり，電気化学協会に入会してから 35 年近くたって しまいました，電気化学をやって本当によかったと思うだけにこ こらで協会にご恩返しでもしなければんいう気持になります。

7 年前に比べ緑の多くなったキャンパスで，活発な討論と楽しい 交歓が行われ，実りある大会になることを祈っています。

大会実行委員長 埼玉大学理学部化学科 (票338 浦和节下大久保 255) 